\title{
Research on Intragenerational Distribution Justice of Double-Track Reform of Primary Endowment Insurance
}

\author{
Yu Zhang \\ East China University of Political Science and Law, Shanghai, 201620, China
}

Keywords: Primary endowment insurance, Double-Track reform, Intragenerational distribution

\begin{abstract}
In October 1, 2014, China formally implemented the reform of the dual track pension system, which is also known as the "parallel" reform. The connotation of the distributive justice of the primary endowment insurance is "the equal distribution of contribution and treatment". However, the intragenerational primary endowment insurance after reform is only fair in the starting point (system), which is unfair in the result (treatment). The main reason is the difference between occupational pension and enterprise annuity. By improving the annuity system and reducing the strange rate of payment, the government will perform the "bottom line responsibility". The way that the government takes the cost of reform can promote the realization of the intragenerational allocation justice of pensions.
\end{abstract}

\section{Content and Result of Double-Track Reform of Primary Endowment Insurance}

In the second half of 2014, the decision of the State Council on the reform of the old-age insurance system for staff in institutions and institutions (hereinafter referred to as the decision) was promulgated by the State Council, which stipulates that the pension insurance system for staff in institutions and institutions has been reformed since October 1, 2014. The staff of nearly 40 million institutions and institutions pay the same fee as the employees of the enterprise, which means that the basic pension is formally tied up.

The old age insurance system between the civil servants and the employees of the institutions has basically differentiated the "double track" system with the basic old-age insurance system for the employees. The new system has been adjusted in terms of pension payment and payment. Under the double track system, the pension payment methods, payment methods and standards of the institutions and enterprises are different. On the way of payment and payment, the pension payment of the employees of an enterprise is paid by individuals and units from their own self raised accounts, while the employees of government offices and institutions are all paid and paid by the state finance. And the standard of pension payment for staff and workers in institutions and institutions is much higher than that of the employees of the enterprise. After the merger reform, the decision made clear the basic old-age insurance system established by the public institutions and enterprises, and the way of paying the units and individuals. The pension payment is also linked to the personal payment of the employees. After the reform, the specific payment and payment methods are listed as follows.

The double track system to get rid of the completion system on the merger, but as pension benefit a wide range of social security system, only focus is clearly one-sided in the optimization of the top-level design, the key lies in whether the reform of pension benefits allocation of different social groups tend to be fair, then before the reform of promoting social fairness in the sense of pension allocation.

Based on this background, this paper studies the two track pension reform in our country, with the generation of distribution from the perspective of emphasis on pension distributive justice, objective is to evaluate the current endowment insurance in our country after the reform is improving the generation of unfair distribution, to explore the problem facing the reform, and put forward the improvement suggestions according to the real reason, realizing the justice of distribution of endowment insurance in generation. 
Table 1. Basic policy of primary endowment insurance after amalgamation

\begin{tabular}{|c|c|c|c|}
\hline & & Payment & Treatment(Month standard) \\
\hline \multirow[t]{2}{*}{$\begin{array}{l}\text { Primary } \\
\text { endowment } \\
\text { insurance }\end{array}$} & $\begin{array}{l}\text { Social coordinate } \\
\text { account }\end{array}$ & $\begin{array}{l}\text { Enterprise: } \\
20 \% \text { of salary }\end{array}$ & $\begin{array}{l}\text { Primary endowment insurance = (monthly average salary } \\
\text { of the local workers in the last year and the monthly } \\
\text { payment of the wages of the employees) } / 2 * \text { year n\% }\end{array}$ \\
\hline & $\begin{array}{l}\text { Individual } \\
\text { account }\end{array}$ & $\begin{array}{l}\text { Employee:8\% } \\
\text { of salary }\end{array}$ & Account accumulation /number of months m \\
\hline \multirow{3}{*}{$\begin{array}{l}\text { Personal } \\
\text { annuity } \\
\text { account }\end{array}$} & $\begin{array}{l}\text { Occupational } \\
\text { pension account }\end{array}$ & $\begin{array}{l}\text { Enterprise: } \\
8 \% \text { of salary }\end{array}$ & \multirow{2}{*}{$\begin{array}{l}\text { Occupational pension account accumulation /number of } \\
\text { months m; or one-time purchase of commercial pension } \\
\text { insurance }\end{array}$} \\
\hline & & $\begin{array}{l}\text { Employee:4\% } \\
\text { of salary }\end{array}$ & \\
\hline & $\begin{array}{l}\text { Enterprise } \\
\text { annuity account }\end{array}$ & $\begin{array}{l}\text { No definite } \\
\text { provision }\end{array}$ & No definite provision \\
\hline
\end{tabular}

\section{Distribution Justice of Primary Endowment Insurance}

\subsection{Dimension Definition of Intragenerational Distribution}

Based on the perspective of equitable distribution in the generation, intra generation equity is the prerequisite and foundation for the realization of intergenerational equity. If people in the contemporary are difficult to feel fair enough, but the requirements for future generations of contemporary people to fulfill responsibility, justice for future generations, the pursuit of fairness and development of their own development not to harm future generations for the price, obviously with the rational person egoism is inconsistent, fairness and justice for future generations more it is difficult to achieve. Therefore, it is difficult to pursue a more long-term intergenerational equity when the fairness of the generation cannot be realized. The inner exist injustice and not be resolved this injustice to the future development of the future generations will have a greater impact. Secondly, the problem of distributive justice within the generation of contemporary society have a more direct impact. The social instability factors caused by the social welfare system are not uncommon in the world. Taking France as an example, the social and regional social movements and demonstrations caused by the welfare treatment every year are hundreds of times. The discussion of the distributive justice in the generation is more necessary and urgent.

According to the actual point of view, public officials present basic reform direct object pension system for the institutions, the workers and enterprises in the pension system on the convergence, to solve the dual system of the disparity and distribution caused by injustice. Combined with the horizontal dimension of the "generation within", this paper discusses the distribution justice problem of pension in public institutions and public employees after merging.

\subsection{Principles and Standards of Intragenerational Distribution Justice}

Combining the two parts of endowment insurance including payment and payment, the distribution not only refers to the redistribution of income, but also means the distribution of rights and obligations. Therefore, the principle of distributive justice in the generation should be understood as the "equal distribution of contribution and treatment" between the staff and the employees in the 
contemporary organs and institutions, which means that rights and responsibilities are mutually exclusive and complementary.

The realization of fairness does not mean the "average" of the treatment, but the corresponding response to the achievement of the contribution and treatment. If the concept of "egalitarianism" to change the "fair", will be on the Department to create new unfair. There is a certain pension gap between public employees and employees, which reflects the level of different professions, and reflects the difference between their industries and jobs. Most of the OECD national civil servants' pension replacement rate is higher than other types of workers but is different from our country the gap are kept in a reasonable range of acceptable, the replacement rate trends are basically the same, and both the level of treatment are more than the United Nations minimum security level. According to the situation of our country, the standard of distributing the justice within the pension system should be as follows: the pension generation rate of the staff and workers in the organs and institutions and enterprises is all above the reasonable level, and a certain gap should be kept within a reasonable range.

Based on this, the comparative criteria for assessing the distribution justice in the generation should adopt the pension replacement rate rather than the absolute amount of the pension. The main point of view is that the reasonable level of the average pension replacement rate in China is between 50\%-60\%. The International Labor Organization (1991) believes that the minimum pension replacement rate is 55\%, and less than 55\% cannot maintain the standard of living before retirement. Based on this standard, the pension allocation of different groups should be combined with their contribution contributions and their treatment income to keep the gap within a reasonable range, but the trend is basically flat, which is the distribution state for justice.

\section{Intragenerational Distribution Justice Analysis of Double-Track Reform of Primary Endowment Insurance}

\subsection{Fair achieved in starting point}

From October 1, 2014, the pension insurance of the institutions and enterprises and the employees of the enterprises began to be on track, and all kinds of workers participated in the basic pension insurance. Employees of civil servants and institutions, as well as employees of enterprises, begin to pay the pension insurance premiums and use the same formula.

After the reform, the equity of the starting point is realized from the contribution point of contribution. Multi-channel financing mechanism of old-age security of the staff and workers of institutions by the financial contributions from the main channel is into a single unit and individual payment, financial commitment of the endowment insurance fund financing fallback responsibility, forming a new mechanism of units and individuals, government sharing, the basic old-age insurance system and the enterprise workers the same system. Hence the pension insurance institutions and corporate pension insurance system was improved to some extent before the system unfair phenomenon, promote the horizontal social justice, is to promote the offer in tribute to pay old-age insurance for different types of units of staff of the same generation fair. The basic endowment insurance has realized the fairness of the starting point in the horizontal distribution, or the system is fair.

\subsection{Fair not achieved in the result}

China's pension insurance is based on the "three pillar" mode. The pension is composed of the first level basic pension, the second level supplementary pension and the third level personal savings pension combination. At the level of distribution, the distribution of pension is not only a part of the basic pension, but also other supplementary parts, such as personal account and occupation, occupational pension, also play an important role in distribution. Therefore, when discussing the issue of distribution, it is not limited to the part of the basic pension, but to avoid the important

influence of the supplementary pension. In combination with the various parts of the pension distribution, there is still a gap and injustice among the different groups in the generation after the 
same period. The significant gap of the pension replacement rate still exists after the two groups of groups, which shows that the unfair distribution is still not solved. On the one hand, the principle of equal distribution of contribution and treatment has not yet been achieved due to the significant gap in treatment. On the other hand, the low pension replacement rate of employees is also a failure to realize their basic old-age security.

\section{Substantial Causes of Distribution Injustice after Double-Track Reform}

\subsection{Differentiated policy formulation as the primary cause}

The gap left by the dual track pension treatment affects the present generation of distribution. The pension treatment of workers and staff members in public institutions in China started from the 1991 decision on the reform of pension insurance system for employees and was divided into two different social systems. It is our country from planned economy to market economy and the transformation of the special product, in 1990s, the reform of state-owned enterprises due to the impact of the traditional labor insurance system for different enterprises need to balance the cost burden of retirement and setting different endowment insurance policy. Among them, the old-age insurance system of public institutions is responsible for the personnel department, so it is superior to the employees in the pension amount or the pension replacement rate. This gap is still clearly reflected in the system after the reform. In the reform, the pension treatment of the workers and workers in the institutions and institutions is "not reduced", and the level of the pension is guaranteed.

Secondly, in the part of supplementary pension insurance, because of the difference between occupational pension and occupational pension system, there are differences between annuity payment rate and tax system, forming "invisible double track system". There is an essential difference between the current enterprise and occupational pension (Table 2). In addition, the current occupational annuity and the enterprise annuity cannot be transferred.

Table 2. Differences between Occupational Annuity and Enterprise Annuity

\begin{tabular}{|c|c|c|c|}
\hline & Establishment system & Contribution ratio & Tax incentives \\
\hline Occupational annuity & Mandatory & Clear regulation and & Duty-free \\
& establishment & high ratio & \\
\hline \multirow{2}{*}{ Enterprise annuity } & Recommended & Prescribed scope and & $4 \%$ of salary \\
& establishment & low ratio & \\
\hline
\end{tabular}

The above three points decide the huge difference in supplementary pension, and the overall level has not changed significantly before the reform, forming the "hidden double track system" which many people worry about. It is estimated that about 20 million workers in the country have enterprise annuity. If both are not equal in the annuity supplementary pension, the reform belongs to the exchange of non-exchange. If the formation of unsolved latent double track system, in the allocation of pension generation within the unfairness problem is still not improved.

\subsection{Injustice aggravated by unbalanced responsibility of government and enterprise}

The development of the annuity in China is lagging, which leads to the unfair distribution of the pension between the two groups of people in the generation. The coverage of occupational pension in China is narrow. In 2013, the number of employees in occupational pension accounts for only $2.2 \%$ of the working age population. The proportion of most OECD countries is much higher than that of China. Even the number of employees in Belgium and Germany is over 50\%. In addition, the role of Chinese enterprise annuity is weak. The replacement rate of enterprise annuity in China is less than $1 \%$, which is almost negligible. In China, the average replacement rate of pension insurance in OECD countries is $60 \%$, and the average annuity replacement rate in China is as high as $23 \%$. The substitution rate of pension in China mainly depends on the basic endowment insurance, and the 
substitution rate of the enterprise annuity is far lower than that of the OECD country. In the absence of enterprise annuity, the merger of the pension reform of the "five simultaneous" clear "occupation pension and the basic old-age insurance system is established, the synchronization" in the part of the supplementary pension after the merger reflects the obvious gap, and the role of the total pension replacement rate gap.

The main reason for the lagging of the enterprise annuity development is that the responsibility of the government and the enterprise is unbalanced, which aggravates the unfair distribution of the pension.

The important reason for the high rate of payment in China is the imbalance of government responsibility. In the process of the reform process and the market transformation of endowment insurance, endowment insurance in our country from the system to fund accumulation system, which leads to linear implicit debt has a large number of transition costs, and the government through the provision of financing mode will bear the transition cost responsibility onto the personal and corporate body, government itself is not fill in cost, which leads to the government are transferred to the enterprise payment pressure. After the reform, the government has not improved the payment of the pension insurance for the employees of the enterprises, and the enterprises still bear a higher rate of payment. Facing the establishment of occupational annuity, part of the gap between the employees and the employees in institutions and institutions is more and more obvious. However, under the condition of lack of government responsibility, it is unfair to continue to ask enterprises to increase their burden.

\subsection{Injustice of intragenerational distribution may aggravated by double-track reform}

The merger reform put public servants in public institutions and institutions into the pension payment system, and ended their original welfare pension system, which inevitably brings about the cost of transition. Before the reform, the pension of public servants in government departments and enterprises was completely borne by the finance, without the accumulation of payment part and personal account. After that, the problem of the pension account was added, namely the solution to the cost of transition. According to estimates, such as to take a one-time pension fund account to eliminate transition costs.

The huge cost of transition has the possibility of being transferred to the employees of the enterprise, aggravating the unfair distribution of the pension. If the transition cost completely by the financial burden, so the enterprise staff does not exist, but China itself facing pension fiscal problems, "China pension development report" shows that as of the end of 2012, China's pension income over expenditure in the province increased year by year, the cumulative gap reached 120 billion 500 million yuan. And through the data, we can find that, in the face of the huge transformation cost after the reform, there is almost no possibility of full financial burden. In the next 30 years, China's pension insurance will face severe pressure of payment, financial sustainability is worrying and full of challenges.

If the cost of transfer is shared by the employees of the enterprise, it will further aggravate the unfair distribution in the generation. It is difficult to filled in the financial institutions public officials in the merger after the reform of the pension accounts, if this part is included in the basic pension insurance fund employees, will inevitably lead to the payment and value-added burden also passed on to employees who. In the case of the obvious pension treatment gap between the two groups of people, this way is bound to aggravate the unfairness of the distribution in the generation.

\section{Suggestions for Improvement of Intragenerational Distribution Justice}

Before the reform of the double track system, the main reason for the criticism of the pension insurance system is the unfair treatment between the two types of workers. Endowment insurance is an important social security mechanism to guarantee the retirement life of the elderly. Its reform goal will promote the distribution equity, and the realization of intra generation fair distribution is more urgent. Therefore, in the specific system design and structure mode, we should follow the value orientation of promoting the equity of distribution and guaranteeing the basic life of the elderly. 
However, after the reform of the dual track system, the pension replacement rate between public officials and employees in the institutions and institutions is still very wide. Of course, the pursuit of "contribution and equal treatment allocation in one generation of distributive justice, the pursuit of rights and responsibility in opposition to each other and complement each other does not mean the difference between pension erase two categories of workers, civil servants civil servants and institutions have the right to keep their privileges in the occupation pension, reflect the difference of fairness, but must be the difference keep in a reasonable scope. According to the above data, the organs and institutions of Public Servants Pension Replacement Rate after the reform is the reform before the decline, but still maintained at a high level, and the enterprise workers' pension replacement rate is still in the International Labor Organization in 55\% under the line, even lower than the lower limit of a reasonable range of China's $50 \%$ generation. The problem of unfair distribution is still significant. To eliminate such unfair distribution, we should take measures to effectively improve the pension benefits of employees to achieve a reasonable replacement rate standard and narrow the gap between the two groups.

\subsection{Improve Enterprise Annuity System}

After the reform of the system, the difference between the workers and the employees of the enterprise is mainly determined by the difference between occupational pension and enterprise annuity. Therefore, we can optimize the annuity system to improve the pension level of the employees and achieve the integration of the second pillar supplementary pension through the opportunity of the reform of the merger system and the development of occupational annuity bankrupt enterprise annuity to promote the intra generation distribution equity.

Promote the enterprise to increase the coverage of the legislative level years. February 2018 began to implement the "enterprise annuity method" promulgated by the Ministry of human resources and the Ministry of finance, the departmental rules and regulations, compared with 2004 promulgated the "Trial Measures for enterprise annuity" and "enterprise will voluntarily established enterprise annuity" changed to "proposed", to a certain extent the weakening of the voluntary and mandatory but compared to the establishment of occupation pension there is still a big difference. The occupational pension plan of organs and institutions is promulgated by the general office of the State Council and belongs to administrative regulations. Compared with the "enterprise annuity", the legislative level is much higher. The development of the enterprise annuity to a certain extent restricted to the level of legislation, laws and regulations are more chaotic system, the operation is not standardized, the implementation of difficult problems, by improving the legislative level, to a certain extent can solve these problems, and gradually weaken its voluntary nature, thus expanding the coverage of enterprise annuity.

\subsection{Appropriately reduce enterprise payment and government fulfills the Bottom Line Responsibility}

The proportion of pension payment in China is relatively high, and the shift of transition cost leads to the heavy burden of enterprises, which makes it unable to establish corporate annuity, resulting in the vacancy of employees in the second pillar of supplementary pension insurance. By taking the burden of basic old-age insurance by the government and decreasing the contribution rate of enterprises, the potential of enterprise annuity can be released, and the level of pension benefits of employees can be raised from the overall level.

Reducing the payment rate of enterprises and promoting the development of the second pillar. If China's enterprises develop annuity in the payment of basic pension insurance after the completion of the general, total contribution rate will reach $20 \%$ (basic pension) $+5 \%$ (enterprise annuity) $=25 \%$, compared with other countries, employers in the United States two payment of up to 20.26\%, Canada is about $14 \%$, our country enterprise payment burden is too heavy. We should appropriately reduce the basic rate of the basic pension insurance and reduce it to the unit payment part of the enterprise annuity, and at the same time, combined with the preferential tax policy of the enterprise annuity, we can effectively promote the function of the enterprise annuity as the second pillar. However, this requires a large amount of calculation to ensure that the reduction of the basic contribution rate should 
be effectively converted to the contribution of the annuity.

\subsection{Government fulfills reform cost}

The merger after the reform of the outstanding problems of civil servants and workers of institutions were exposed and established after the reform of the personal account of existing debts problem, this part of the cost of reform such as the contribution to enterprise workers' pension insurance fund will transfer pressure to employees who, in the generation of aggravated unfair distribution. And the pension of public service officials is completely responsible by the finance. After the reform, this part of the responsibility should be undertaken by the government. This will certainly be a huge financial expenditure, but some scholars think that the scale of fiscal expenditure can be affordable after analyzing the structure of fiscal expenditure.

\section{Conclusion}

There is a clear inequity in the distribution of endowment insurance between generations under the dual track system. Therefore, it is imperative to combine reform with the goal of promoting intra generation distribution justice. In the pension replacement rate as evaluation criteria, which have reached a reasonable level, may be appropriate to retain a certain gap, but the control in the reasonable scope, guarantee the generation of internal organs and institutions and enterprises of their respective basic pension needs of workers.

To promote the realization of the distribution justice in the generation, the level of the pension treatment for the employees of the enterprises should be promoted effectively. By improving the enterprise annuity system, enhance the enterprise annuity development legislation level, improve tax exemption of enterprise annuity incentive to enhance the security level of the second pillar; lowering the peculiar contribution rate, by the government to fulfill the "bottom line responsibility", maintain the first pillar of the security level; to avoid the double track system reform costs to the enterprise employees and to make the nominal account system ease the financial pressure.

\section{References}

[1] Huang Jianyuan, Liu Yumei, Wang Huan. Function Analyses of the New Policy of the Endowment Insurance System of the Government Public Institutions: A View of Fairness [J]. Social Security Studies, 2016(2): 19-27.

[2] Guo Jianping, Huang Jianyuan, Miu Junhua. An Analysis of the Forced Effect of Occupational Pension on Enterprise Annuity [J]. Journal of Hohai University (Philosophy and Social Sciences), 2016, 18(5): 32-39+90.

[3] Wang Liguo. Distributive Justice, Fiscal Responsibility and the Pension Institution for Urban and Rural Residents - Based on Jilin Province [J]. Journal of Qiqihar University (Philosophy \& Social Science Edition), 2017(5): 52-55.

[4] Zhang Chun'e, Zhang Shuya. Countermeasures of China's Endowment Insurance Double- track System Reform [J]. Modern Industrial Economy and Informationization, 2014(8): 32-34. 